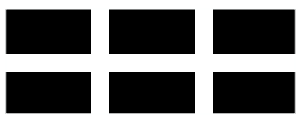

THE WILLIAM DAVIDSON INSTITUTE AT THE UNIVERSITY OF MICHIGAN BUSINESS SCHOOL

\title{
Mind the Break! Accounting for Changing Patterns of Growth during Transition
}

\author{
By: Jan Fidrmuc and Ariane Tichit
}

William Davidson Institute Working Paper Number 643

January 2004 


\title{
Mind the Break! Accounting for Changing Patterns of Growth during Transition ${ }^{\nabla}$
}

\author{
Jan Fidrmuc ${ }^{*}$ and Ariane Tichit ${ }^{* *}$
}

November 2003

\begin{abstract}
We argue that econometric analyses based on transition countries' data can be vulnerable to structural breaks across time and/or countries. We demonstrate this argument by identifying structural breaks in growth regressions estimated with data for 25 countries and 12 years. Our method allows identification of structural breaks at a-priori unknown points in space or time. The only prior assumption is that breaks occur in relation to progress in implementing market-oriented reforms. We find robust evidence that the pattern of growth in transition has changed at least two times, yielding thus three different models of growth associated with different stages of reform. The speed with which individual countries progress through these stages differs dramatically, however.
\end{abstract}

Keywords: Growth, reform, structural breaks, transition.

JEL codes: O47, P26, P27.

\footnotetext{
${ }^{\nabla}$ Preliminary, comments and suggestions welcome. We are grateful to seminar participants at ZEI for many helpful comments.

* Corresponding author. ECARES, Université Libre de Bruxelles; ZEI, University of Bonn; CEPR, London; and WDI, University of Michigan. Address: ECARES, Université Libre de Bruxelles, 50 Avenue F.D. Roosevelt, CP114, 1050 Brussels, Belgium. Email: JFidrmuc@ulb.ac.be. Phone: +32-2-650-4462, Fax: +32-2-650-3369.

TEAM and ROSES, University of Paris 1. Address: 106-112 Bd de l'Hôpital, 75647 Paris Cedex 13, FRANCE, Email: Ariane.Tichit@univ-paris1.fr. Tél:+33 144078244.
} 


\section{Introduction}

Transition is a process of structural change. Market-oriented reform, if implemented effectively, results in rapid and dramatic changes in the regulatory and institutional environment, transfer of ownership from the state to private agents and free setting of prices in commodity and labor markets. State dirigisme is replaced by market economy and individual agents make their decisions pursuing their own best interests. Change is thus the quintessential characteristic, and indeed the objective, of the transition process in the post-communist countries of Central and Eastern Europe. The multifaceted process of change that is so central to transition, however, implies that many fundamental relationships determining how post-communist economies work will in fact change as well. Few students of transition would doubt this simple and uncontroversial observation. Yet, most empirical studies of transition do not account for the changing nature of the relationships they analyze.

Failure to account for structural breaks during transition can have serious consequences as the analysis then utilizes data generated by two (or more) different statistical models. The resulting estimates then reflect only the average of pre- and post-break relationships rather than the two (or multiple) true patterns and are therefore misleading. Adding new observations may change the resulting estimates considerably if the balance between pre- and post-break data is altered. As a consequence, studies addressing the same topic using the same but updated or extended data may find different or even widely diverging results. A good example is the discussion of the impact of market-oriented reform policies on growth, which, following the initial contribution of De Melo, Denizer and Gelb (1996), generated a number of different findings ranging from a strong positive relationship to an insignificant one.

We use the relationship between reform policies and growth to demonstrate the fragility of analytical results obtained with data spanning a large number of years and/or countries. There is already a sizeable literature on this issue of potentially great importance - whether progress in implementing market-oriented reform delivers higher growth. The discussion was spurred by the finding of De Melo et al. (1996) of a strong positive relationship in a cross section of 26 countries, with data covering the early 1990s. The defining characteristic of the ensuing debate was a general lack of consensus (see, for example, De Melo, Denizer and Gelb, 1996; Havrylyshyn, Izvorski and van Rooden, 1998; Krueger and Ciolko, 1998; Heybey and Murrell, 1999; Berg et al., 1999; Wolf, 1999; Fischer and Sahay, 2000; Popov, 2000; and the survey by 
Campos and Coricelli, 2002). While several studies replicated the finding of a positive impact of reform policies on growth, others countered with findings of a weak or insignificant relationship.

Most previous analyses do not consider the possibility of structural breaks and simply pool all available countries and years. Yet, economic growth is one of the processes where one should anticipate dramatic changes in the course of transition. First, progress in market-oriented reform should improve the allocation of resources and increase the efficiency of their use, thus delivering higher growth. Second, a reform effort of a given magnitude may have dramatically different repercussion if implemented in the context of a centrally planned economy and in a partial or nearly full-fledged market environment. Some studies do split the data arbitrarily into groups of countries or sub-periods. Selowsky and Martin (1997) and Tichit (1999) analyze separately the Central and Eastern European countries and the former Soviet Union and find substantial differences between the two sub-groups. Fidrmuc (2003) estimates his regressions for different periods and, also, finds substantial differences. Yet, the various post-communist countries implemented market-oriented reforms at different pace and with varying resolve, while some even experienced temporary or sustained reform reversals. At any point in time, therefore, some countries will be closer to becoming market economies than others and may therefore belong to different models of growth. Then, while arbitrarily partitioning of the data may improve on regressions estimated with pooled data, one is little likely to partition the data exactly at the true location of structural breaks.

We employ an analytical method that allows us to determine the presence of (potentially multiple) structural breaks in the data at ex-ante location. We do so by testing for structural breaks in both time and space, specifically allowing for individual countries to follow different models of growth at any given point in time. In this manner, structural breaks are identified based on statistical inference about differences in patterns of growth rather than our prior beliefs about which countries or which years should be lumped together. The only prior belief that we impose on the analytical algorithm is an assumption that structural breaks occur in relation to progress in implementing market-oriented reforms. We believe this assumption to be reasonable: given that the very objective of transition is transforming centrally-planned economies into market-based ones, one may expect those proceeding more rapidly to experience structural change earlier than those dragging their feet on reform.

A side product of our analysis is that we construct a new measure of progress in implementing market-oriented reforms (which is central to our analysis). Previous studies 
typically used a simple average of the eight progress-in-transition indicators reported annually by the European Bank for Reconstruction and Development (EBRD). However, applying equal weight to these eight indexes is not necessarily justified. Therefore, we construct a weighted reform index with weights determined by factor analysis.

Our findings confirm considerable variation in transition experiences across the different countries. In our baseline model, we find evidence of two structural breaks. Correspondingly, we identify three stable models of growth. As we expected, individual countries make their way through the three models of growth with different speed: while some find themselves in the most advanced stage of growth already by mid 1990s, others remain in the second or even first stage throughout the decade.

The rest of the paper is structured as follows. In the following section, we introduce the data used in our analysis and discuss construction of the weighted reform index. Section 3 presents the results and Section 4 summarizes our conclusions.

\section{Data}

The socialist countries shared a number of important factors that should have predestined them to grow at respectable rates: high investment rates, educated and skilled labor and relatively low income levels ${ }^{1}$. Yet, as has been recognized by a number of analysts (see in particular Ofer, 1987; and Easterly and Fischer, 1995), they failed to use the available resources efficiently and therefore, after the potential for extensive growth was exhausted, economic development came to a halt during the 1980s. The subsequent reforms, however, fell short of delivering universally shared improvement and instead lead to a great variety of outcomes. While some countries resumed growth after a few years of a transformational recession, others experienced severe and protracted declines with little subsequent recovery. To demonstrate this variation in outcomes, Figure 1 reports cumulative growth between 1989 and 2001 for the 25 post-communist countries for which data are available. On the one hand, Slovenia and Poland have seen their GDP rise by 17 and 27 percent, with further five countries also reporting positive cumulative growth. On the other hand, most transition economies report negative cumulative growth and some of the former Soviet Republics even found themselves in 2001 at output levels less than half those attained

\footnotetext{
${ }^{1}$ A common finding in the growth literature is the so-called conditional convergence, i.e. poor countries tend to grow faster, after controlling for other determinants of growth (see Barro, 1991; Levine and Renelt, 1992; and Mankiw, Romer and Weil, 1992).
} 
before the transition began. In general, the Central and Eastern European Countries (CEECs) returned to positive growth 2 or 3 years after the beginning of transition whereas the former Soviet Union (FSU) countries experienced prolonged periods of economic decline (4-5 years or even longer).

\section{Figure 1 Cumulative Growth, 1989-2001}

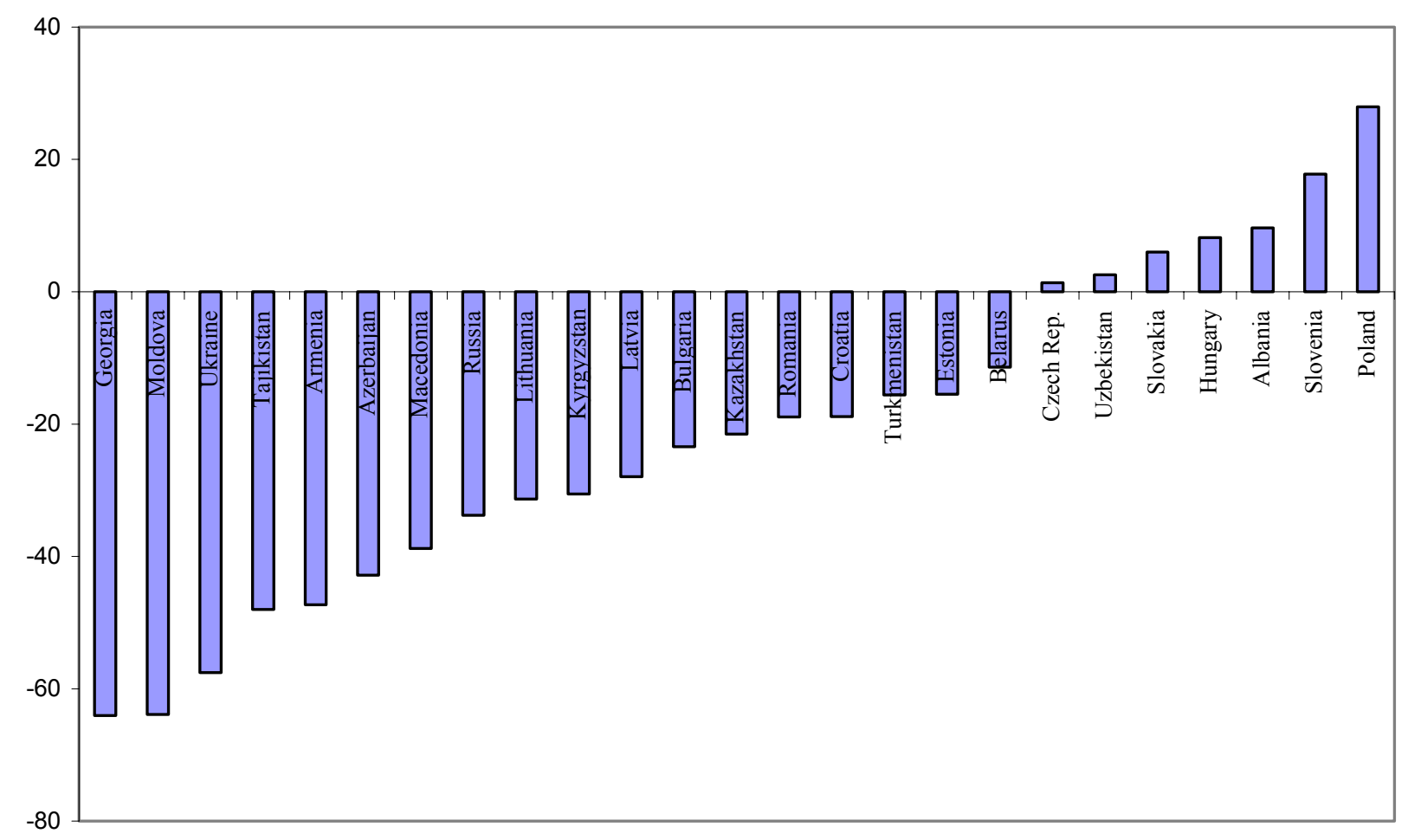

As the aim of the paper is to test whether the post-communist transition countries follow different models of growth depending on their degree of progress towards a market economy, the first problem to settle is to find an accurate measure of this progress. The EBRD offers diverse quantitative indicators to take into account the many facets of the transformation. Each year it provides figures for 8 variables taking the values 0 to 1 , to measure the progress in each of the following fields: Price liberalization, Foreign exchange and Trade Liberalization, Small Scale Privatization, Large Scale Privatization, Enterprise Reform, Competition Policy, Banking Reform and Non-banking Financial Institutions. If these different indicators measure the same phenomenon - the progress towards the market economy - they must be closely related. Table 1, listing the coefficients of correlation between the country averages of the eight EBRD indexes, 
clearly shows that there is a high degree of dependency between them. In particular, the following pairs of sub-indexes show very high correlation: enterprise and banking reforms (90.8\%), the foreign exchangeltrade liberalization with banking reform (80.4\%) and with price liberalization $(80 \%)$. In general, competition policy is less correlated with the other variables. Those results reflect between-countries correlations, as they are calculated with average values for the period 1990-2001. While carrying out the same exercise year by year, some variation appears (see annex), but the main conclusions do not change.

Table 1: Percentage of common variation between EBRD indicators

\begin{tabular}{|c|c|c|c|c|c|c|c|c|}
\hline & Price Lib & $\begin{array}{l}\text { Forex/Trade } \\
\text { Lib }\end{array}$ & $\begin{array}{l}\text { Small } \\
\text { Scale } \\
\text { Priv } \\
\end{array}$ & \begin{tabular}{|l|} 
Large \\
Scale \\
Priv \\
\end{tabular} & $\begin{array}{l}\text { Ent. } \\
\text { Reform }\end{array}$ & $\begin{array}{l}\text { Comp. } \\
\text { Policy }\end{array}$ & \begin{tabular}{|l} 
Bank \\
Reform \\
\end{tabular} & \begin{tabular}{|l|} 
Non- \\
bank. \\
Fin. Inst. \\
\end{tabular} \\
\hline Price Liberalization & 100 & & & & & & & \\
\hline Forex/Trade Liberalization & 80.0 & 100 & & & & & & \\
\hline Small Scale Privatization & 64.5 & 71.0 & 100 & & & & & \\
\hline Large Scale Privatization & 38.4 & 58.0 & 52.7 & 100 & & & & \\
\hline Enterprise Reform & 53.3 & 64.5 & 59.4 & 72.5 & 100 & & & \\
\hline Competition Policy & 16.3 & 22.7 & 22.1 & 45.9 & 59.2 & 100 & & \\
\hline Banking Reform & 71.7 & 80.4 & 66.7 & 70.6 & 90.8 & 41.4 & 100 & \\
\hline Non-bank. Financial Inst. & 30.1 & 35.7 & 36.0 & 49.0 & 69.8 & 68.3 & 61.5 & 100 \\
\hline
\end{tabular}

Note: Correlations calculated on average values of EBRD indicators for 1990-2001.

Source: EBRD Transition Report 2003.

Because of the high correlation between the various sub-indexes, previous studies typically used their simple average so that the eight measures were reduced to one. However, to the best of our knowledge, none of these studies tested whether assigning equal weight is in fact appropriate. Therefore, as the first step in our analysis, we perform a factor analysis to determine if all the eight EBRD indicators measure the same phenomenon - the evolution towards market economy or if they reflect independent information contained in some of the sub-indexes. Moreover, while computing a general aggregated index, this method ensures finding the appropriate weight for each of the sub-indexes in a composite weighted-average reform index.

In application, there are not one but several factor analysis models which differ in significant respects. A model most often applied is called common factor analysis (or principal component analysis). Common factor analysis is concerned with defining the patterns of common variation among a set of variables. Variation unique to a variable is ignored. In contrast, another factor model called component factor analysis is concerned with patterning all the variation in a set of 
variables, whether common or unique. We use the second method, as it allows to determine the degree of unique variation for each indicator.

What we try to do is to find a good indicator of the degree of progress towards becoming fullfledged market economies. This variable is unobserved. What we have is a set of indexes that are trying to measure the progress in different policies aimed at transforming the economy. The component factor analysis pursues this objective by estimating the following equation system:

$$
\begin{aligned}
& Y_{1}=x_{11} F_{1}+x_{12} F_{2}+\ldots+x_{1 m} F_{m}+\varepsilon_{1}, \\
& Y_{2}=x_{21} F_{1}+w_{22} F_{2}+\ldots+x_{2 m} F_{m}+\varepsilon_{2}, \\
& Y_{3}=x_{31} F_{1}+x_{32} F_{2}+\ldots+x_{3 m} F_{m}+\varepsilon_{3}, \\
& \ldots \\
& \ldots \\
& \ldots \\
& Y_{n}=x_{n 1} F_{1}+x_{n 2} F_{2}+\ldots+x_{n m} F_{m}+\varepsilon_{n},
\end{aligned}
$$

where $\mathrm{Y}$ is a variable with known data (in our case, the eight EBRD indicators), $a$ are the loadings (constant), $\mathrm{F}$ is a function, $\mathrm{f}(\mathrm{)}$ of some unknown variables and $\varepsilon$ the variation of $\mathrm{Y}$ that is independent of the factors.

It is crucial in understanding factor analysis to remember that $F$ stands for a function of variables and not a variable. By application to the known data on the $\mathrm{Y}$ variables, factor analysis defines the unknown $F$ functions. The factors are the $\mathrm{F}$ functions. The size of each loading for each factor measures how much that specific function is related to Y. We may find that some of the $\mathrm{F}$ functions are common to several variables. These are called group factors. To decide how many factors to retain, we use the common criteria of an eigenvalue higher than 0.5 . The eigenvalue of the first factor is 6.12 while that for the second one is 0.39 . Therefore, we only retain the first factor. The results of the estimation are reported in Table 2.

The first column shows the factor loadings which are the coefficients of correlation between each EBRD indicator and the factor. We can see that all indicators are strongly positively related to the factor. This reveals that the factor clearly represents the progress towards creating a market economy. The second column gives the communality for each variable. It corresponds to the percentage of variation of the indicator that it is linked to the factor. ${ }^{2}$ The communalities are very high for each variable, reaching on average $76.5 \%$ of total variance. Finally, the last column shows the uniqueness of each variable, which depicts the percentage of total variation that is autonomous. Of course, the sum of the last two columns for each row must be equal to 100 . The

\footnotetext{
${ }^{2}$ The communality for each variable is the square of the loading multiplied by 100 .
} 
results indicate that the most independent indicator is price liberalization. Nevertheless, all the percentages of uniqueness are far less than 50\%, implying that all the variables are highly correlated among themselves. Computing a common factor analysis (which assumes that all the communalities are equal to 1) indeed gives almost the same loadings as the component factor analysis (unreported results).

Table 2: Factor analysis

\begin{tabular}{|l|c|r|c|c|}
\hline Variable & Factor 1 & Communality & Uniqueness & Weights \\
\hline Price liberalization & 0.77 & $59.7 \%$ & $40.3 \%$ & 0.06519 \\
Foreign exchange/trade lib. & 0.90 & $81.3 \%$ & $18.7 \%$ & 0.15068 \\
Small privatization & 0.91 & $83.0 \%$ & $17.0 \%$ & 0.18246 \\
Large privatization & 0.89 & $78.7 \%$ & $21.3 \%$ & 0.09828 \\
Enterprise reform & 0.94 & $88.4 \%$ & $11.6 \%$ & 0.22190 \\
Competition liberalization & 0.81 & $65.6 \%$ & $34.4 \%$ & 0.10091 \\
Bank liberalization & 0.94 & $87.8 \%$ & $12.2 \%$ & 0.18599 \\
Non bank liberalization & 0.82 & $67.7 \%$ & $32.3 \%$ & 0.08338 \\
\hline Percentage of total variation & - & $76.5 \%$ & $23.5 \%$ & \\
\hline
\end{tabular}

Using factor analysis, it is possible to endogenously determine the weight for each indicator in the aggregate index of the progress towards a market economy (Factor 1). The resulting scores are reported in the last column of in Table 2. As one can see, the highest weights are assigned to enterprise reform, small scale privatization and banking sector liberalization. These are the three most important components of the composite index of the degree of economic liberalization. Multiplying the scores and the values of the sub-indexes yields for each year and each country the index of progress towards a market economy. The aggregate index takes the values from -1.34 (most of the countries at the beginning of transition) to +1.93 (Hungary in 2000 and 2001). The average level of the index for each country over the period 1989-2001 is reported in Figure 2. 


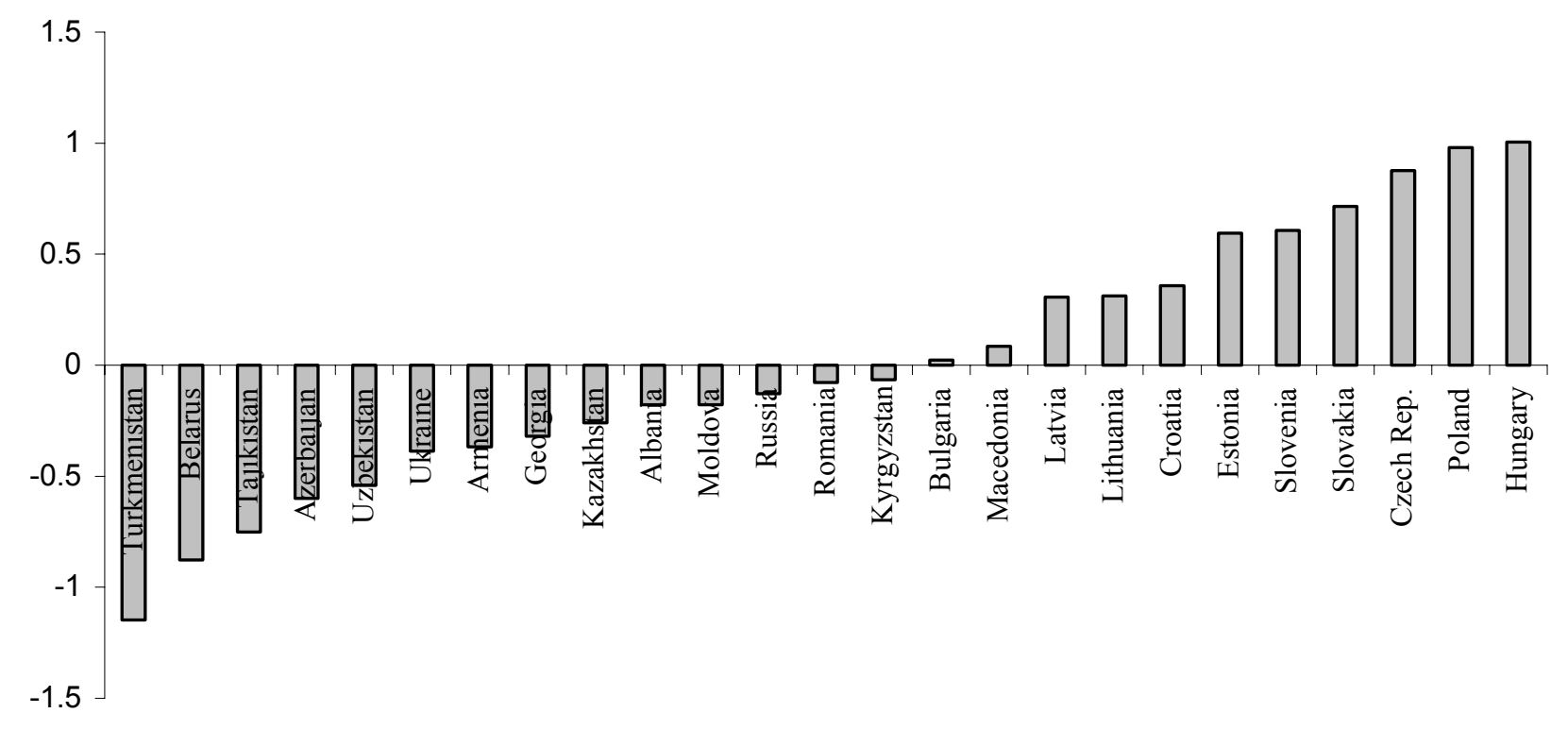

Note: The figure reports country averages over 1989-2001.

The former Republics of the USSR progressed more slowly in liberalization of their economy: almost all these countries have a negative average index. Only the Baltic Republics report positive average values of the indicator. Turkmenistan lags furthermost behind. If we look at the evolution of the index over time (see annex 1), it is interesting to note that Croatia, Macedonia, Slovenia and to a lesser extend Hungary and Poland began their transition with a relatively high degree of liberalization. In 1989 the indicator's value of the first three countries is comparable to those of Belarus and Turkmenistan in 1998. In general, the FSU countries began with the lowest level of the indicator and improved it more slowly (except the Baltics). Moreover, they are the only countries experiencing reversals in the index's evolution. For example, Belarus improved its index up to -0.17 in 1995 but subsequently the index fell again, reaching -0.78 in 1999. In 2001 the index is still lower than the 1995 performance (only -0.738). The highest level of the indicator among the FSU is Russia in 1997 (0.738) but decreases thereafter. Kyrgyzstan in 1997 and 1998 takes the second place. Those figures are nonetheless far lower than those of the CEECs which in general have a positive value of the indicator after 5 years of transition (ie.1994) as opposed to the FSU (including the Baltics) which reach it only after 1997 (8 years of 
transformation). Overall thus, the evolution of the countries according to their progress towards a market economy is very heterogeneous and does not monotonically depend on time, suggesting that the factors governing growth are indeed sensitive to the progress in implementing reforms.

\section{Structural Breaks in Growth during Transition}

The conventional approach to finding structural breaks entails applying the Chow test (see Chow, 1960; and Greene, 1997, chapter 7.6) at a point determined with the help of theory or based on observation of stylized facts such as a permanent change in trend. In this analysis, while we anticipate that transition will bring about a break in the underlying model of growth (and possibly multiple structural breaks), we do not have a clear-cut prior belief that the break should occur at a specific point in time or in space. Or, to be precise, we have too many plausible break points such as CEE vs FSU (with the Baltic countries alternatively included with the former or the latter), EU accession-candidate countries vs the rest, the mid point of transition (alternatively measured in calendar or transition time, with the latter counting years since transition began in each particular country), etc. Therefore we apply a methodology (following Bai, 1997, and Bai and Perron, 1998) that allows us to identify a-priori unknown structural breaks. In essence, our approach involves testing for structural breaks across all possible partition of the data into two sub-samples. The point of partition that yields the highest (significant) value of the test statistic identifies a structural break. Note that several partitions may yield significant values of the test statistic but only the partition with the highest value is taken as a true structural break. The algorithm is then repeated on the two resulting sub-intervals, until no significant test statistic can be found.

As our data contain 300 observations ( 25 countries over 12 years), the number of possible partitions is extremely large. Moreover, finding structural breaks based on random partitioning of the data would not be very illuminating as it would be difficult to ascertain what factors are responsible for the occurrence of the breaks. Therefore, we adopt a simplifying assumption, namely that the occurrence of the break is related to the progress in implementing economic reforms. Given that we are interested in identifying structural breaks that occur in the course of transition from central planning to market economy, this assumption seems justified. Accordingly, we order the data by the value of the weighted reform index (described above), and perform the partition and compute test statistic for each value of the index. 
We estimate the following baseline model:

$$
\Delta Y_{j, t}=f\left(R I_{j, t}, R I_{j, t-1}, D I_{j, t} I_{j}, \operatorname{LINFL}_{j, t} W A R_{j, t} \operatorname{SECSCH}_{j}, \Delta P O P_{j, t}\right)
$$

where the dependent variable, $\Delta Y_{j, t}$, is the growth rate in country $j$ in year $t$. The explanatory variables include: the reform index $(R I)$, including one lag; a democracy index, $D I$, which is the average value of the indicators of political freedoms and civil liberties reported by the Freedom House and rescaled to range between zero (no democracy) and one (full democracy); a composite index of initial conditions constructed by the EBRD, $I C_{j}$, (measuring macroeconomic distortions, time spent under communism, distance to the EU, dependence on CMEA for trade and natural resource wealth $)^{3}$; logarithm of CPI inflation, $L I N F L_{j, t}$; a dummy indicating whether the country was involved in a military conflict (internal or external) during the year, $W A R_{j, t}$; secondary school enrollment as of late 1980s, $S E C S C H_{j}$; and annual population growth, $\triangle P O P_{j, t}$. We tested whether fixed or random effects have to be included and found that we can estimate the model as pooled cross section. The reform index, initial conditions, inflation and the war dummy are variables that have been prominently used in the literature on growth during transition (see, for example, De Melo, Denizer and Gelb, 1996; Aslund, Boone and Johnson, 1996; Havrylyshyn, Izvorski and van Rooden, 1998; Berg et al., 1999; Wolf, 1999; Falcetti, Raiser and Sanfey, 2002; or Radulescu and Barlow, 2002). ${ }^{4}$ School enrollment and population growth are included because they are among the variables found to be important as determinants of growth in general (see Barro, 1991; or Levine and Renelt, 1992). We would have liked to include investment and government consumption as these also have been found to have important effects on growth performance but that causes too many missing observations, in effect reducing the amount of available data by more than a third.

The results are summarized in Table 3. The first column reports regression results obtained with the full sample. This model, however, is found to be unstable in that it contains a structural break at a value of the reform index equal to -0.7843 with a test statistic that is highly significant. The regression results for the resulting two sub-intervals are reported in columns (2) and (3). The algorithm is then repeated on each sub-interval. The first regression model is found to be stable (although the test statistic for a structural break at index taking value -0.8862 is close to being

\footnotetext{
${ }^{3}$ This measure is the first factor (out of two) resulting from principal component analysis of a number of initial conditions, see Box 2.1 in the EBRD Transition Report 1999, and Falcetti, Raiser and Sanfey (2002). We Follow Falcetti et al. (2002) who argue that only the second factor is not robustly related to growth and only use the first one.

${ }^{4}$ The democracy index has not been as frequently used in the literature as the other variables. Therefore, we reestimated the model without democracy but the results remain largely the same (and, importantly, the location of the structural breaks is the same with or without including the democracy index in the regression).
} 
significant). The second regression model contains another structural break at reform index equal to 0.7191 . No further structural breaks are found subsequently so that the models reported in columns (4) and (5) are stable.

The analysis thus yields three stable models of growth for the following reform index intervals: $[-1.3440,-0.7843),[-0.7843,0.7191)$ and $[0.7191,1.9326]$. For simplicity, we refer to these intervals as the pre-reform, early reform and late reform models of growth, respectively. ${ }^{5}$ The first, pre-reform model thus refers to the stage in transition before rigorous reforms are implemented. The second and third models then comprise observations with intermediate and advanced progress in reform. Note that countries can progress from one model to another at different points in time (if ever) and can also revert back to a previously abandoned model.

\footnotetext{
${ }^{5}$ It is very well possible that with further data, another model will be identified. Therefore, we leave the postreform model label available for future research.
} 
Table 3 Structural Breaks in the Baseline Model of Growth

\begin{tabular}{|c|c|c|c|c|c|c|c|c|c|c|}
\hline \multirow{2}{*}{$\begin{array}{l}\text { Index range: } \\
\text { Stability of model: } \\
\text { Reform index }\end{array}$} & \multicolumn{2}{|c|}{$\begin{array}{l}\text { Full sample } \\
\text { Unstable model } \\
(1)\end{array}$} & \multicolumn{2}{|c|}{$\begin{array}{c}\text { [Min; } \mathbf{- 0 . 7 8 4 3 )} \\
\text { Stable model } \\
(2)\end{array}$} & \multicolumn{2}{|c|}{$\begin{array}{c}\text { [-0.7843, Max] } \\
\text { Unstable model } \\
(3)\end{array}$} & \multicolumn{2}{|c|}{$\begin{array}{c}{[-0.7843,0.7191)} \\
\text { Stable model } \\
(4)\end{array}$} & \multicolumn{2}{|c|}{$\begin{array}{c}\text { [0.7191; Max] } \\
\text { Stable model } \\
(5)\end{array}$} \\
\hline & -2.632 & $(1.49)$ & $-18.979 * *$ & $(2.24)$ & -1.747 & $(0.90)$ & -1.108 & $(0.44)$ & -4.096 & $(1.35)$ \\
\hline Reform index lagged & $6.868 * * *$ & $(4.05)$ & $51.767 * * *$ & $(5.80)$ & $5.684 * * *$ & $(3.77)$ & $4.578 * *$ & $(2.46)$ & $5.070 * *$ & (2.19) \\
\hline Democracy & $-9.823 * * *$ & $(4.03)$ & 2.455 & $(0.45)$ & $-9.468 * * *$ & $(3.40)$ & $-17.168 * * *$ & $(4.18)$ & -0.363 & $(0.13)$ \\
\hline Inflation (log) & $-1.529 * * *$ & $(5.80)$ & $-1.911 * * *$ & $(3.66)$ & $-1.377 * * *$ & $(4.27)$ & $-1.617 * * *$ & $(3.73)$ & 0.553 & $(1.31)$ \\
\hline War Dummy & $-9.615 * * *$ & $(6.45)$ & $-9.970 * * *$ & $(4.52)$ & $-8.377 * * *$ & $(4.16)$ & $-9.605 * * *$ & $(4.11)$ & & \\
\hline Sec. school enrollment & -0.038 & $(0.63)$ & 0.193 & $(1.53)$ & $-0.142 * *$ & $(2.24)$ & $-0.232 * *$ & $(2.55)$ & -0.039 & $(0.72)$ \\
\hline Population growth & 0.394 & $(0.95)$ & $1.779 * *$ & $(2.00)$ & 0.598 & $(1.27)$ & 0.353 & $(0.57)$ & -0.057 & $(0.11)$ \\
\hline EBRD IC1 measure & 0.358 & $(1.37)$ & -0.032 & $(0.04)$ & 0.264 & $(1.06)$ & $0.831 * *$ & $(2.17)$ & -0.350 & $(1.47)$ \\
\hline Intercept & $13.734 * * *$ & $(2.63)$ & $26.618 * *$ & $(2.21)$ & $21.948 * * *$ & $(3.98)$ & $34.025 * * *$ & $(4.27)$ & 6.174 & $(1.24)$ \\
\hline $\mathrm{R}^{2}$ & 0.5676 & & 0.6313 & & 0.5466 & & 0.5643 & & 0.1228 & \\
\hline F-stat / p-value & 42.66 & 0.00 & 13.70 & 0.00 & 28.18 & 0.00 & 19.10 & 0.00 & 1.22 & 0.3059 \\
\hline $\mathrm{N}$ & 269 & & 73 & & 196 & & 127 & & 69 & \\
\hline Break located at & -0.7843 & & -0.8862 & & 0.7191 & & 0.3552 & & 1.4059 & \\
\hline Chow test stat ${ }^{1}$ & 5.77 & & 1.908 & & 2.126 & & 1.466 & & 0.737 & \\
\hline Critical value & 1.88 & & 2.07 & & 1.88 & & 1.98 & & 2.02 & \\
\hline
\end{tabular}

\begin{tabular}{lccc} 
Critical value & 1.88 & 2.07 & 1.88 \\
\hline Notes: Standard errors are in parentheses. Significance levels are indicated as $1 \%(* * *), 5 \%(* *)$ & and $10 \%(*)$.
\end{tabular}

${ }^{1}$ Chow test statistic for the presence of another structural break. Bold font indicates that the break is significant. 
Clearly, using a different regression specification could lead us to identify different structural breaks. Therefore, to test the robustness of our results, we repeated the analysis with four alternative regression specifications. Omitting the democracy index, the first structural break at 0.7843 is reproduced but no further significant break points can be identified afterwards, suggesting that there may be only two stable models. Omitting school enrollment from the baseline model resulted in same breaks as in the baseline model (note however that the suspected break at index value -0.8862 is very close to being significant, see Table A2). The last structural break is identical to those obtained with the baseline model, occurring at index value of 0.7191 . When omitting population growth or both population growth and school enrollment from the baseline model (see Tables A3 and A4, respectively), the first break occurs at a slightly lower value of the reform index, -0.8862 . The test also identifies an additional break at -0.8862 . The pre-reform model thus spans the shorter interval $[-1.3440,-0.8862)$. This results in an additional 'model', which, however, contains only ten observations (because of the low number of observations, no regression results are reported). This additional structural break may indicate a disproportionate amount of noise (e.g. measurement error) in some of those ten observations that makes them stand apart from either of the adjacent intervals. ${ }^{6}$ The last structural break occurs again at 0.7191 .

Importantly, the regression results obtained with the four alternative regression models are very similar to the one obtained with the baseline model. Omitting the democracy index strengthens the significant of the reform index, which confirms that the two variables are correlated. Furthermore, in the regressions without population growth and without both population growth and school enrollment, the measure of initial conditions becomes significant and negative in the late reform stage, indicating that countries with adverse initial conditions tend to report a better growth performance (in contrast to the early reform stage when adverse initial conditions hinder growth). Given the similarity of the results, the discussion in the remainder of our paper centers on the baseline regression model reported in Table 3 .

Table 4 reports the average values of growth, inflation and the reform index for the three models. The pre-reform period is associated with serious economic malaise, countries in this stage on average decline by over $9 \%$ per year and experience price increases of hyperinflationary proportions, over $800 \%$ per year. Compared to that, the second model presents a marked

\footnotetext{
${ }^{6}$ These twelve observations are Armenia 1994, Belarus 1998-2000, Bulgaria 1991, Hungary 1990, Lithuania 1992, Romania 1992, Ukraine 1994, and Turkmenistan 1997-99.
} 
improvement: although growth remains negative, the decline slows down considerably to $2 \%$ per year and inflation falls to $200 \%$. Finally, countries in the late reform category grow nearly $4 \%$ per year with inflation only at $13 \%$.

\section{Table 4 Descriptive Statistics}

\begin{tabular}{|c|c|c|c|c|c|c|}
\hline \multirow[b]{2}{*}{ Model } & \multicolumn{3}{|c|}{ MEANS } & \multicolumn{3}{|c|}{ STANDARD DEVIATIONS } \\
\hline & Growth & Inflation & Reform index & Growth & Inflation & Reform index \\
\hline 1 (Pre-reform) & -9.230667 & 842.8703 & -1.163464 & 11.57453 & 2033.249 & 0.1951703 \\
\hline 2 (Early reform) & -2.119847 & 226.8466 & 0.1019761 & 8.72021 & 418.2046 & 0.4529174 \\
\hline 3 (Late reform) & 3.734783 & 13.36667 & 1.250008 & 2.795313 & 10.54381 & 0.2884506 \\
\hline
\end{tabular}

Notes: Models 1, 2 and 3 refer to the three stable models reported in Table 1 in columns (2), (4) and (5), respectively.

A question of great interest, of course, is which countries belong to each model of growth at which time. In principle, a country in transition should proceed through all three stages, although the speed, or the time spend in each stage, may differ. Table 5 presents a tabular representation of the distribution of countries into the three models over time. Poland and the former Yugoslavia are found in the second, early transition model already as early as 1990 . This does not imply that these countries never experienced central planning, rather, it reflects their progress in implementing partial reforms already in the course of the 1980s (and in case of the former Yugoslavia, even before that). Hungary and the former Czechoslovakia join this group in 1991, followed by the Baltic countries in 1992-93. The rest of CEE, European FSU countries (except those in the Caucasus), and Kyrgyzstan also progress to the early reform model in the first half of the 1990s. The Czech Republic, Hungary, Poland, Slovakia, Slovenia, Croatia and the Baltics are again the first to reach the late-reform model of growth, to which they progress between 1993 and 1996. In contrast, the other countries go much more slowly through each stage. The Southern European and European FSU countries reach the early reform stage in the first half of the 1990s, but then remain there until 2001 (the end of our data), except for Bulgaria, Macedonia and Romania, which move to the late reform stage in 1999-2000 and Russia, which finds itself in the third stage in 1997 but leaves it again the following year (apparently in connection with its financial crisis of 1998). The FSU countries in the Caucasus and Central Asia only graduate to the early reform model by mid decade and then stay there, except Kyrgyzstan, which makes the first leap already by 1993 and then briefly, and just barely, makes it to the late reform model in 1997 and 1998. Finally, Turkmenistan and Belarus show rather disappointing performance, with 
the former never leaving the pre-reform model of growth and the latter reversing the early progress in reform so that it reverts from the early transition stage back to the pre-transition one in 1998 and stays there through 2000.

Much of the discussion on the patterns of growth during transition centered on the role of liberal policies in delivering efficiency improvements that lead to higher growth. However, that discussion has so far been largely inconclusive: while some argue that progress in liberalization improves growth (see De Melo, Denizer and Gelb, 1996; Havrylyshyn, Izvorski and van Rooden, 1998; or Berg et al., 1999), others suggest that initial conditions or the fact that progress in liberalization is endogenous in economic performance explain most of the differences in growth patterns (see Krueger and Ciolko, 1998; and Heybey and Murrell, 1999). Yet, essentially all of these studies were conducted using data pooled either across countries or time (or both). Hence, they fail to account for the changing nature of growth and therefore it is not at all surprising that they often arrive at very different findings.

In contrast, the regression results reported in Table 4 are estimated with data that is free of structural breaks. Therefore, it is instructive to compare the impact of liberal policies, and other factors, on growth in the three stages of reform. ${ }^{7}$ Liberalization in all three models has a negative contemporaneous effect on growth while its lagged effect is positive. The coefficient on the lagged term is always larger in absolute value than that for the contemporaneous term, indicating that the cumulative impact of liberalization on growth is positive. Moreover, the contemporaneous, negative effect is not significant in the second and third stages while the lagged positive one always is. Last but not least, the impact of liberalization is at its strongest in the pre-reform period when an increase in the reform index by 1 increases growth cumulatively by $33 \%$ over two years (a decrease of $19 \%$ in the first year followed by an increase of $52 \%$ in the second year). ${ }^{8}$ The gains from liberalization are much more modest in the other two models, $3 \%$ in the early reform and $0.7 \%$ in the late reform stage. Thus, laying the institutional foundations of the market economy brings much greater benefits in terms of economic growth than the subsequent adjustment and fine-tuning of reforms.

\footnotetext{
${ }^{7}$ Recall that the three stable models are reported in columns (2), (4) and (5).

${ }^{8}$ Recall that the reform index that we use ranges between -1.34 and 1.93 .
} 
Table 5 Evolution of Growth Patterns across Countries and Time

\begin{tabular}{|c|c|c|c|c|c|c|c|c|c|c|c|c|}
\hline & 1990 & 1991 & 1992 & 1993 & 1994 & 1995 & 1996 & 1997 & 1998 & 1999 & 2000 & 2001 \\
\hline Albania & 1 & 1 & 2 & 2 & 2 & 2 & 2 & 2 & 2 & 2 & 2 & 2 \\
\hline Armenia & 1 & 1 & 1 & 1 & 1 & 2 & 2 & 2 & 2 & 2 & 2 & 2 \\
\hline Azerbaijan & 1 & 1 & 1 & 1 & 1 & 2 & 2 & 2 & 2 & 2 & 2 & 2 \\
\hline Belarus & 1 & 1 & 1 & 2 & 2 & 2 & 2 & 2 & 1 & 1 & 1 & 2 \\
\hline Bulgaria & 1 & 1 & 2 & 2 & 2 & 2 & 2 & 2 & 2 & 3 & 3 & 3 \\
\hline Croatia & 2 & 2 & 2 & 2 & 2 & 2 & 3 & 3 & 3 & 3 & 3 & 3 \\
\hline Czech Rep. & 1 & 2 & 2 & 3 & 3 & 3 & 3 & 3 & 3 & 3 & 3 & 3 \\
\hline Estonia & 1 & 1 & 2 & 2 & 3 & 3 & 3 & 3 & 3 & 3 & 3 & 3 \\
\hline Georgia & 1 & 1 & 1 & 1 & 1 & 2 & 2 & 2 & 2 & 2 & 2 & 2 \\
\hline Hungary & 1 & 2 & 2 & 3 & 3 & 3 & 3 & 3 & 3 & 3 & 3 & 3 \\
\hline Kazakhstan & 1 & 1 & 1 & 1 & 2 & 2 & 2 & 2 & 2 & 2 & 2 & 2 \\
\hline Kyrgyzstan & 1 & 1 & 1 & 2 & 2 & 2 & 2 & 3 & 3 & 2 & 2 & 2 \\
\hline Latvia & 1 & 1 & 2 & 2 & 2 & 2 & 3 & 3 & 3 & 3 & 3 & 3 \\
\hline Lithuania & 1 & 1 & 1 & 2 & 2 & 3 & 3 & 3 & 3 & 3 & 3 & 3 \\
\hline Macedonia & 2 & 2 & 2 & 2 & 2 & 2 & 2 & 2 & 2 & 2 & 3 & 3 \\
\hline Moldova & 1 & 1 & 1 & 2 & 2 & 2 & 2 & 2 & 2 & 2 & 2 & 2 \\
\hline Poland & 2 & 2 & 2 & 3 & 3 & 3 & 3 & 3 & 3 & 3 & 3 & 3 \\
\hline Romania & 1 & 1 & 1 & 2 & 2 & 2 & 2 & 2 & 2 & 2 & 3 & 3 \\
\hline Russia & 1 & 1 & 2 & 2 & 2 & 2 & 2 & 3 & 2 & 2 & 2 & 2 \\
\hline Slovakia & 1 & 2 & 2 & 3 & 3 & 3 & 3 & 3 & 3 & 3 & 3 & 3 \\
\hline Slovenia & 2 & 2 & 2 & 2 & 3 & 3 & 3 & 3 & 3 & 3 & 3 & 3 \\
\hline Tajikistan & 1 & 1 & 1 & 1 & 1 & 2 & 2 & 2 & 2 & 2 & 2 & 2 \\
\hline Turkmenistan & 1 & 1 & 1 & 1 & 1 & 1 & 1 & 1 & 1 & 1 & 1 & 1 \\
\hline Ukraine & 1 & 1 & 1 & 1 & 1 & 2 & 2 & 2 & 2 & 2 & 2 & 2 \\
\hline Uzbekistan & 1 & 1 & 1 & 1 & 2 & 2 & 2 & 2 & 2 & 2 & 2 & 2 \\
\hline
\end{tabular}

Notes: The Table shows which model of growth a country belongs to in any given year between 1990 and 2001 .

Models 1, 2 and 3 refer to the three stable models reported in Table 1 in columns (2), (4) and (5), respectively. 
It is interesting to note also that democracy appears to have a negative effect on growth in the early reform stage. This may be due to increased political uncertainty associated with democratization (the reformist government can be voted out of office and replaced by one less inclined to continue the reform). Moreover, a government facing election may choose to pursue policies that maximize its political support in the short term but do not lead to efficiency improvements in the long run. However, Fidrmuc (2003) who finds a similar effect of democracy argues that this negative coefficient is due to the strong correlation between the reform and democracy indexes. When he controls for this relationship, he finds that democracy has a positive overall impact on growth.

Inflation lowers growth in the pre-reform and early reform models of growth but not in the late reform model, possibly because inflation is generally low in this stage. This is consistent with the finding reported by Bruno and Easterly (1996) that only high inflation (above 40\%) is detrimental to growth. Being involved in a military conflict, not surprisingly, has a strong adverse impact on growth (none of the countries in the late reform model of growth were affected by wars, therefore, the war dummy had to be omitted in the last regression).

The result obtained for secondary school enrollment is surprising: it is insignificant in the prereform and late reform stages but negative and significant in the early reform model, thus indicating that countries with higher better human capital in fact grow more slowly. However, a number of potential culprits can be listed to explain this counter-intuitive finding 9 : school enrollment reported in late 1980 s may be subject to measurement errors or misreporting, the figure may be no longer relevant in the mid and late 1990s as the stock of human capital has been altered in the meantime by migration and new developments in schooling, and education acquired in communist education system may not be easily transferable to a market environment.

Population growth seems to encourage economic growth in the pre-reform stage. This may be due to prevalent dependence on the extensive pattern of growth under central planning (i.e. faster population growth translates into greater input of labor). Moreover, the positive coefficient may also reflect the fact that the break-up of the former Soviet Union and Yugoslavia brought about sizeable migratory movements of people in prime age.

\footnotetext{
${ }^{9}$ Such counter-intuitive findings are, however, not entirely unusual in the transition growth literature. Campos, 2001, for example, finds that in some regression specifications, investment appears to have a negative impact on growth while in others government expenditure seems to encourage growth - both findings being in stark contrast to the patterns found for developed countries.
} 
The EBRD indicator of initial conditions is only significant in the early-reform stage when countries with a greater extent of macroeconomic imbalance grew less dynamically (or, as was often the case, declined more rapidly). The lack of a significant impact of initial conditions on growth in the first model is surprising, considering the attention that this relationship has received in the literature (see Aslund et al., 1996; Krueger and Ciolko, 1998; and Heybey and Murrell, 1999). For the late reform stage, our finding of no effect parallels those of Berg et al. (1998) and Falcetti et al. (2002). We further explored the potential role of initial conditions by testing for presence of structural breaks in growth according to the different values of the initial conditions measure. However, we found no structural breaks in this manner. Hence, while progress in implementing economic reforms is related to the occurrence of structural breaks, the patterns of growth during transition do not appear to differ across countries with different initial conditions.

Finally, the last, late-reform model has rather low overall explanatory power (the F-statistic indicates in fact that the regression as a whole is not significant) and only the lagged reform index turns out with a significant coefficient. This may be because of the relatively low number of observations, or it is an indication that the pattern of growth during that stage is still undergoing further changes. More data will be needed to a get better estimate of the model of growth during the third stage.

\section{Conclusion}

In this paper, we use the heterogeneous growth experiences of post-communist countries to demonstrate the changing nature of fundamental economic relationships during transition. As the various elements of the market environment are implemented, one can see, indeed one should expect to see, important changes concerning the way the transition economies work. Facilitating such changes, after all, is the very objective of the reform.

Presence of structural breaks, however, implies that empirical analyses of transition must account for the changing nature of the relationships studied, otherwise the findings will be misleading. In our analysis of the relationship between reform-oriented policies and growth, we found evidence of two structural breaks. Moreover, individual countries may experience the breaks at different points in time. In our data covering 25 countries and 12 years, for example, almost half of the countries have not yet experienced the second structural break and one has not even experienced the first one. 
While we demonstrate the fragility of econometric results using a specific relationship that has aroused much interest in the transition literature, our argument is likely to be valid more generally. Therefore, this paper constitutes a cautionary tale for any empirical analyst studying multiple countries and/or longer time periods during transition: structural breaks are likely during transition, and may occur in time and in space alike.

Our analysis also sheds new light on the much-disputed relationship between reform-minded policies and growth during transition. For our base model, we find evidence of two breaks and thus three different models of growth, which we refer to as pre-reform, early reform and late reform pattern of growth. Individual countries go through the three stages of growth at dramatically different speed: while some progress to the late reform model three or four years after the beginning of transition, others take much longer or remain in the early reform model until the end of our period. The growth determinants are significantly different between the models. Therefore, the presence of structural break may account for the differences in findings reported by previous studies, which typically differed from each other concerning the number of countries and even more periods covered by their analyses. The impact of reform-minded policies indeed weakens as countries move closer to becoming market economies, hence one is more likely to find a significant relationship using data from the early part of transition than with a longer data set.

We find that contemporaneous liberalization has a significantly negative effect on growth only in the pre-reform period. The lagged effect, in contrast, is positive and significant in all of the three models. The cumulative effect of liberalization (the sum of the contemporaneous and lagged effects) is largest in the pre-reform stage. Rather surprisingly, we find that democracy hurts growth performance, although only in the second, early-reform stage of growth. This may indicate that the political and policy uncertainty associated with political liberalization had adverse economic repercussions during the early reform stage. Finally, in contrast to previous literature, we find that initial conditions do not have an overwhelming effect on growth. Even more importantly, we were unable to identify any structural breaks in the pattern of growth based on cross-country differences in initial conditions. In summary, we show that the pattern of growth changes in relation to progress in implementing market-oriented reforms. Nevertheless, we did not consider the issue of endogeneity of progress in reform, which has been raised in a number of recent studies. This question still remains open for further research. 


\section{References}

Aslund, Anders, Peter Boone and Simon Johnson (1996), "How to Stabilize: Lessons from Postcommunist Countries," Brookings Papers on Economic Activity 1, 217-291.

Bai, Jushan (1997), "Estimation of a Change Point in Multiple Regression Models," Review of Economics and Statistics 79 (4), 551-563.

Bai, Jushan and Pierre Peron (1998), "Estimating and Testing Linear Models with Multiple Structural Changes," Econometrica 66 (1), 47-78.

Barro, Robert (1991), "Economic Growth in a Cross Section of Countries," Quarterly Journal of Economics 106, 407-443.

Berg, Andrew, Eduardo Borensztein, Ratna Sahay and Jeronim Zettelmeyer (1999), The Evolution of Output in Transition Economies: Explaining the Differences, IMF Working Paper WP/99/73.

Bruno, Michael and William Easterly (1996), "Inflation Crises and Long-Run Growth," Journal of Monetary Economics 41 (1), 3-26.

Campos, Nauro F. (2001), "Will the future be better tomorrow? The growth prospects of transition economies revisited," Journal of Comparative Economics 29 (4), 663-676.

Campos, Nauro F. and Fabrizio Coricelli (2002), "Growth in Transition: What We Know, What We Don't, and What We Should," Journal of Economic Literature XL, 793-836.

Chow, Gregory (1960) "Test of Equality Between Sets of Coefficients in Two Linear Regressions," Econometrica 28, 591-605.

De Melo, Martha, Cevdet Denizer, and Alan Gelb (1996), "Patterns of Transition from Plan to Market," World Bank Economic Review 10 (3), 397-424.

De Melo, M., Denizer, C., Gelb, A., 1997. Circumstance and choice: The role of initial conditions and policies in transition economies. World Bank Policy Research Paper, The World Bank, Washington, D.C.

Easterly, William and Stanley Fischer (1995), "The Soviet Economic Decline," World Bank Economic Review 9 (3), 341-371.

Falcetti, Elisabetta, Martin Raiser and Peter Sanfey (2002), "Defying the Odds: Initial Conditions, Reforms, and Growth in the First Decade of Transition," Journal of Comparative Economics 30, 229-250.

Fidrmuc, Jan (2003), "Economic Reform, Democracy and Growth during Post-communist Transition," European Journal of Political Economy 19 (3), 583-604.

Fischer, Stanley, and Ratna Sahay (2000), The transition after ten years, IMF Working Paper WP/00/30, February 2000. International Monetary Fund, Washington, D.C.

Greene, William (1997), Econometric Analysis, Prentice Hall: Upper Saddle River, NJ.

Havrylyshyn, Oleh, Ivailo Izvorski, and Ron van Rooden (1998), Recovery and Growth in Transition Economies 1990-97: A Stylized Regression Analysis, IMF Working Paper WP/98/141.

Heybey, Berta, and Peter Murrel (1999), "The Relationship between Economic Growth and the Speed of Liberalization During Transition," Journal of Policy Reform 3 (2).

Krueger, Gary, and Marek Ciolko (1998), "A Note on Initial Conditions and Liberalization during Transition," Journal of Comparative Economics 26, 718-734.

Levine, Ross and David Renelt (1992), "A Sensitivity Analysis of Cross-Country Growth 
Regressions," American Economic Review 82 (4), 942-963.

Mankiw, N. Gregory, David Romer and David N. Weil (1992), "A Contribution to the Empirics of Economic Growth," Quarterly Journal of Economics 107 (2), 407-437.

Ofer, Gur (1987), "Soviet Economic Growth: 1928-85," Journal of Economic Literature XXV, $1767-1833$.

Popov, V., 2000. Shock therapy versus gradualism: The end of the debate (Explaining the magnitude of transformational recession). Comparative Economic Studies 42 (1), 1-57.

Radulescu, Roxana and David Barlow (2002), "The Relationship Between Policies and Growth in Transition Countries," Economics of Transition 10 (3), 719-745.

Selowsky, Marcello, and Ricardo Martin (1997), "Policy performance and output growth in the transition economies," American Economic Review (Papers and Proceedings) 87 (2), 349353.

Tichit, Ariane (1999), Bad Growth Performance of FSU Countries: Does Unemployment Matter?, mimeo.

Wolff, HolgerC. (1999), Transition strategies: Choices and outcomes, Princeton Studies in International Finance No. 85 (June), Department of Economics, Princeton University, Princeton, NJ. 
Annex 1: Percentage of common variation between EBRD indicators

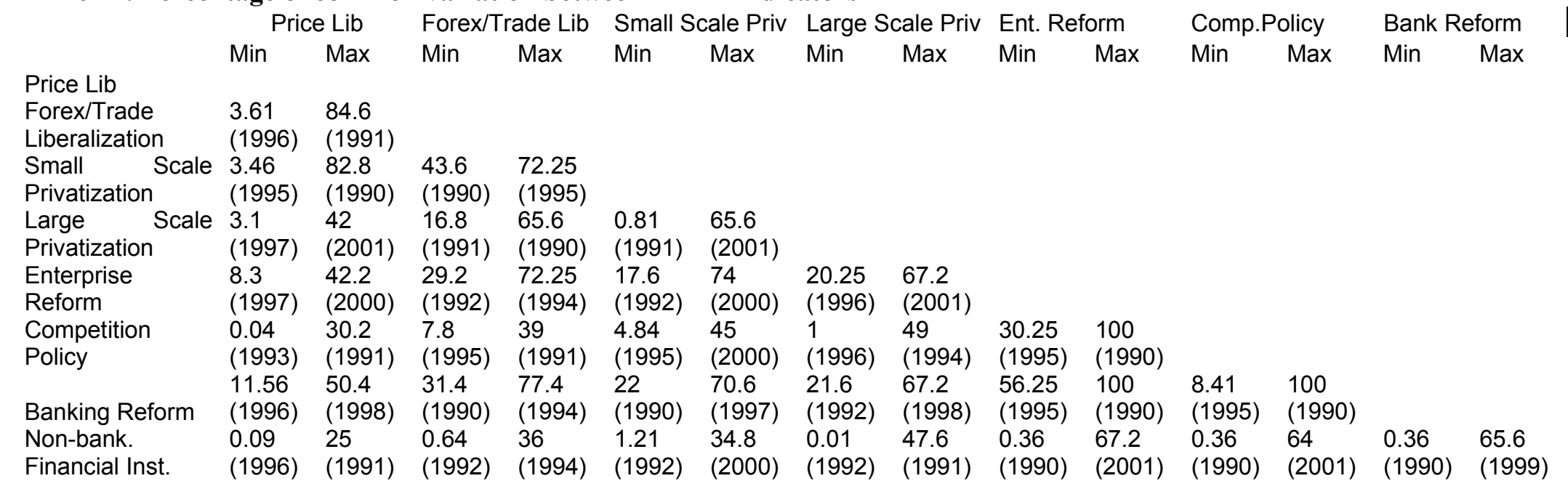

Note: year when minimum and maximum occurs in parenthesis 
Annex 2 : Evolution of the aggregate index by country and by year
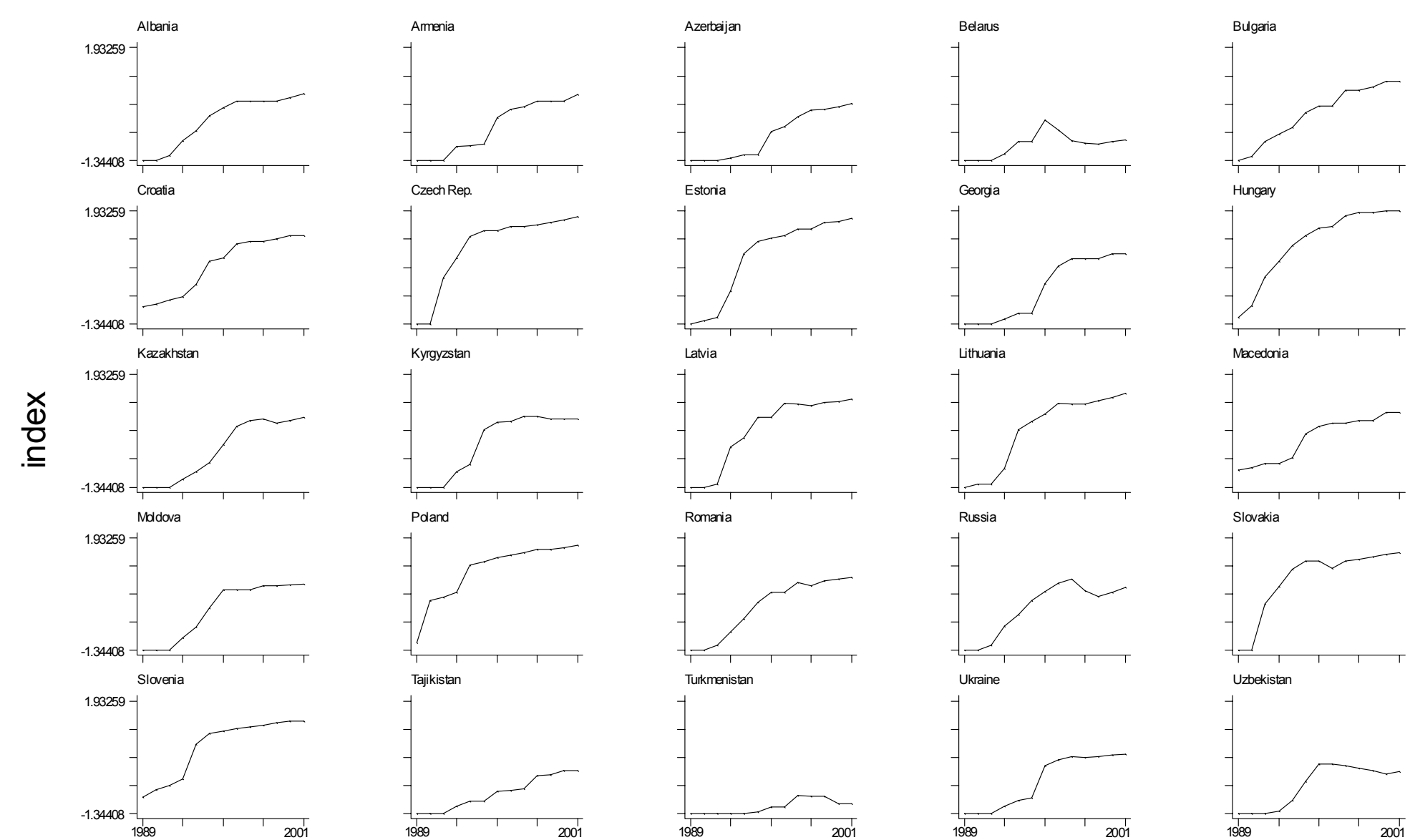

Romania

Russia

Slovakia
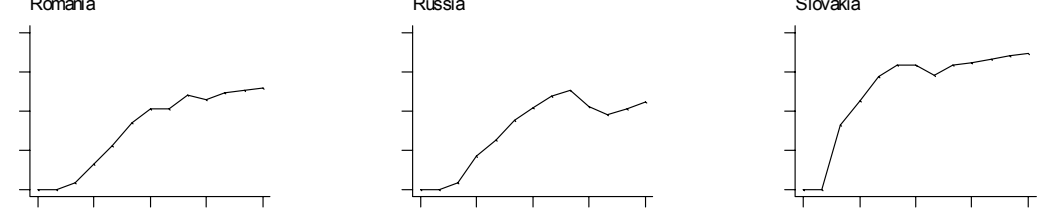

Tajikistan

Turkmenistan

Ukraine
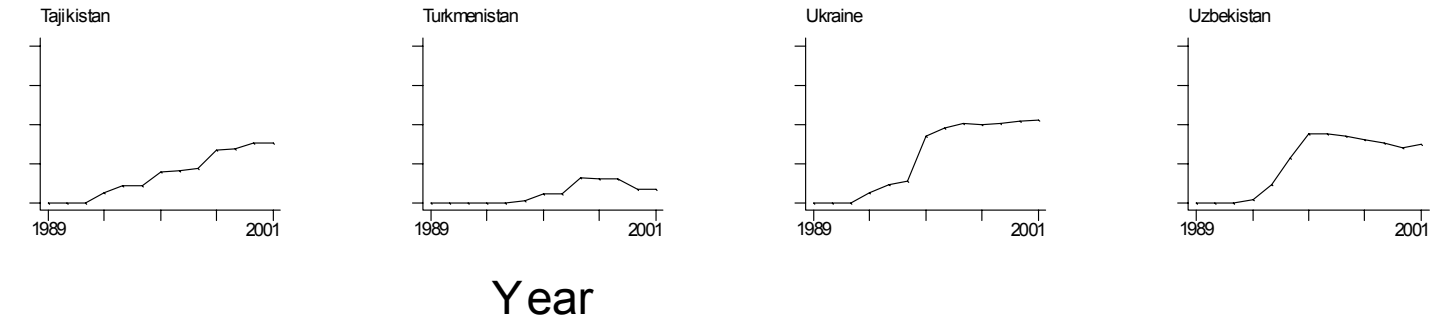

Year 
Annex 3: Robustness Checks: Alternative Regression Models

Table A1 Structural Breaks in a Model without Democracy

\begin{tabular}{l|rrrrrr}
\hline Index range: & \multicolumn{2}{|c}{$\begin{array}{l}\text { Full sample } \\
\text { Unstable model }\end{array}$} & $\begin{array}{c}\text { [Min; -0.7843) } \\
\text { Stable model }\end{array}$ & $\begin{array}{c}\text { [-0.7843, Max] } \\
\text { Stable model }\end{array}$ \\
& $(1)$ & $(2)$ & $(4)$ & \\
\hline Reform index & $-3.980 * *$ & $(1.780)$ & $-18.801 * *$ & $(8.409)$ & $-4.575 * * *$ & $(1.807)$ \\
Reform index lagged & $7.331 * * *$ & $(1.743)$ & $50.618 * * *$ & $(8.501)$ & $6.398 * * *$ & $(1.536)$ \\
Inflation (log) & $-1.510 * * *$ & $(0.271)$ & $-1.901 * * *$ & $(0.519)$ & $-1.581 * * *$ & $(0.326)$ \\
War Dummy & $-9.679 * * *$ & $(1.533)$ & $-9.897 * * *$ & $(2.186)$ & $-8.108 * * *$ & $(2.069)$ \\
Sec. school enrollment & -0.048 & $(0.061)$ & 0.202 & $(0.124)$ & $-0.113 * * *$ & $(0.065)$ \\
Population growth & $0.759 *$ & $(0.416)$ & 1.706 & $(0.868)$ & 1.086 & $(0.460)$ \\
EBRD IC1 measure & -0.214 & $(0.227)$ & $0.130 * *$ & $(0.671)$ & -0.194 & $(0.216)$ \\
Intercept & $9.135 *$ & $(5.242)$ & $25.791 * *$ & $(11.851)$ & $15.722 * * *$ & $(5.340)$ \\
$\mathrm{R}^{2}$ & 0.541 & & 0.630 & & 0.519 & \\
F-stat / p-value & 43.87 & 0.00 & 15.82 & 0.00 & 28.92 & 0.00 \\
N & 269 & & 73 & & 196 & \\
Potential break located at & -0.7843 & & -0.8862 & & 0.3960 & \\
Chow test stat & 7.43 & & 1.96 & & 1.66 & \\
Critical value & 1.94 & & 2.13 & & 1.98 & \\
\hline
\end{tabular}

Notes: Standard errors are in parentheses. Significance levels are indicated as $1 \%(* * *), 5 \%(* *)$ and $10 \%(*)$.

${ }^{1}$ Chow test statistic maximum for the presence of another structural break. Bold font indicates that the break is significant. 
Table A2 Structural Breaks in a Model without School Enrollment

\begin{tabular}{|c|c|c|c|c|c|c|c|c|c|c|}
\hline $\begin{array}{l}\text { Index range: } \\
\text { Stability of model: }\end{array}$ & $\begin{array}{r}\text { Full sample } \\
\text { Unstable m } \\
(1)\end{array}$ & & $\begin{array}{r}\text { [Min; } \mathbf{- 0 . 7 8} \\
\text { Stable mod } \\
(2)\end{array}$ & & $\begin{array}{r}{[-0.7843, \mathbf{N}} \\
\text { Unstable } \mathbf{n} \\
(4)\end{array}$ & & $\begin{array}{c}{[-0.7843,0 .} \\
\text { Stable mod } \\
(5)\end{array}$ & 91) & $\begin{array}{r}7191 ; M \\
\text { Stable } \\
(6) \\
\end{array}$ & \\
\hline Reform index & -2.686 & $(1.758)$ & $-21.574 * *$ & $(8.383)$ & -2.642 & $(1.924)$ & -2.308 & $(2.515)$ & -4.355 & $(3.007)$ \\
\hline Reform index lagged & $6.878^{* * *}$ & $(1.696)$ & $52.654 * * *$ & $(9.004)$ & $5.859 * * *$ & $(1.523)$ & $5.144 * * *$ & $(1.893)$ & $5.036^{* *}$ & $(2.310)$ \\
\hline Democracy & $-9.891^{* * *}$ & $(2.431)$ & 3.863 & $(5.473)$ & $-8.612 * * *$ & $(2.785)$ & $-15.483 * * *$ & (4.149) & -0.044 & $(2.763)$ \\
\hline Inflation (log) & $-1.532 * * *$ & $(0.263)$ & $-1.824 * * *$ & $(0.525)$ & $-1.511 * * *$ & $(0.321)$ & $-1.773^{* * *}$ & $(0.440)$ & 0.514 & $(0.416)$ \\
\hline War Dummy & $-9.531 * * *$ & $(1.483)$ & $-10.199 * * *$ & $(2.223)$ & $-7.903 * * *$ & $(2.025)$ & $-8.703 * * *$ & $(2.364)$ & & \\
\hline Population growth & 0.437 & $(0.408)$ & 1.340 & $(0.849)$ & 0.629 & $(0.475)$ & 0.427 & $(0.637)$ & -0.059 & $(0.498)$ \\
\hline EBRD IC1 measure & 0.387 & $(0.258)$ & -0.109 & $(0.773)$ & 0.356 & $(0.249)$ & $0.969 * *$ & $(0.389)$ & -0.308 & $(0.230)$ \\
\hline Intercept & $10.630 * * *$ & $(1.690)$ & $39.890 * * *$ & $(8.456)$ & $10.226^{* * *}$ & $(1.757)$ & $14.585^{* * *}$ & $(2.409)$ & 2.968 & $(2.191)$ \\
\hline $\mathrm{R}^{2}$ & 0.567 & & 0.618 & & 0.534 & & 0.540 & & 0.115 & \\
\hline F-stat / p-value & 48.82 & 0.00 & 15.02 & 0.00 & 30.82 & 0.00 & 19.97 & 0.00 & 1.35 & 0.25 \\
\hline $\mathrm{N}$ & 269 & & 73 & & 196 & & 127 & & 69 & \\
\hline Potential break located at & -0.7843 & & -0.8862 & & 0.7191 & & 0.378 & & 1.38 & \\
\hline Chow test stat ${ }^{1}$ & 5.74 & & 2.03 & & 2.05 & & 1.74 & & 0.95 & \\
\hline Critical value & 1.94 & & 2.13 & & 1.98 & & 2.03 & & 2.13 & \\
\hline
\end{tabular}

Notes: Standard errors are in parentheses. Significance levels are indicated as $1 \%(* * *), 5 \%(* *)$ and $10 \%(*)$.

${ }^{1}$ Chow test statistic maximum for the presence of another structural break. Bold font indicates that the break is significant. 
Table A3 Structural Breaks in a Model without Population Growth

\begin{tabular}{|c|c|c|c|c|c|c|c|c|c|c|c|c|}
\hline $\begin{array}{l}\text { Index range: } \\
\text { Stability of model: }\end{array}$ & $\begin{array}{r}\text { Full sample } \\
\text { Unstable m } \\
(1)\end{array}$ & & $\begin{array}{r}\text { [Min; } \mathbf{- 0 . 8 0} \\
\text { Unstable } \mathbf{~ m} \\
(2)\end{array}$ & $\begin{array}{l}\text { 2) } \\
\text { del }\end{array}$ & $\begin{array}{r}{[\text { Min; } \mathbf{- 0 . 8 8}} \\
\text { Stable mod } \\
(3)\end{array}$ & & $\begin{array}{r}{[-0.8002, \mathbf{M}} \\
\text { Unstable } \mathbf{m} \\
(4)\end{array}$ & & $\begin{array}{c}{[-0.8002,0} \\
\text { Stable mod } \\
(5)\end{array}$ & 191) & $\begin{array}{r}{[0.7191 ; \mathbf{M}} \\
\text { Stable } \\
(6)\end{array}$ & odel \\
\hline Reform index & -2.643 & $(1.698)$ & $-24.562 * * *$ & $(8.670)$ & $-29.722 * * *$ & $(10.681)$ & -2.343 & $(1.858)$ & -1.362 & $(2.347)$ & -3.418 & $(2.694)$ \\
\hline Reform index lagged & $6.797 * * *$ & $(1.631)$ & $52.020^{* * *}$ & $(9.316)$ & $57.077 * * *$ & $(11.535)$ & $5.880 * * *$ & $(1.460)$ & $4.721 * * *$ & $(1.797)$ & $4.142 *$ & $(2.154)$ \\
\hline Democracy & $-10.535 * * *$ & $(2.226)$ & -0.204 & $(5.617)$ & -0.523 & $(5.680)$ & $-10.170 * * *$ & $(2.459)$ & $-18.471 * * *$ & $(3.672)$ & 1.946 & $(2.624)$ \\
\hline Inflation (log) & $-1.605 * * *$ & $(0.251)$ & $-1.806 * * *$ & $(0.523)$ & $-1.764 * * *$ & $(0.555)$ & $-1.524 * * *$ & $(0.302)$ & $-1.762 * * *$ & $(0.401)$ & 0.429 & $(0.375)$ \\
\hline War Dummy & $-9.587 * * *$ & $(1.438)$ & $-10.098 * * *$ & $(2.268)$ & $-11.696^{* * *}$ & $(2.172)$ & $-8.030 * * *$ & $(1.921)$ & $-9.425 * * *$ & $(2.190)$ & & \\
\hline Sec. school enrollment & -0.053 & $(0.055)$ & 0.123 & $(0.128)$ & 0.160 & $(0.133)$ & $-0.117 * *$ & $(0.058)$ & $-0.216^{*}$ & $(0.083)$ & -0.019 & $(0.049)$ \\
\hline EBRD IC1 measure & 0.218 & $(0.245)$ & -0.726 & $(0.742)$ & $-1.197 *$ & $(0.731)$ & 0.160 & $(0.232)$ & $0.792^{* *}$ & $(0.360)$ & $-0.457 * *$ & $(0.215)$ \\
\hline Intercept & $15.837 * * *$ & $(4.718)$ & $27.134 * *$ & $(12.480)$ & 23.799 & (16.097) & $21.158^{* * *}$ & $(5.017)$ & $34.278 * * *$ & (7.298) & 3.192 & $(4.436)$ \\
\hline $\mathrm{R}^{2}$ & 0.577 & & 0.619 & & 0.658 & & 0.544 & & 0.591 & & 0.122 & \\
\hline F-stat / p-value & 55.73 & 0.00 & 14.82 & 0.00 & 14.81 & 0.00 & 36.42 & 0.00 & 27.48 & 0.00 & 1.72 & 0.13 \\
\hline $\mathrm{N}$ & 294 & & 72 & & 62 & & 222 & & 141 & & 81 & \\
\hline $\begin{array}{l}\text { Potential break located } \\
\text { at }\end{array}$ & -0.8002 & & -0.8862 & & & & 0.7191 & & 0.3694 & & 1.444 & \\
\hline Chow test stat ${ }^{1}$ & 6.44 & & 2.22 & & 1.56 & & 3.31 & & 1.61 & & 0.93 & \\
\hline Critical value & 1.94 & & 2.13 & & 2.13 & & 1.98 & & 2.03 & & 2.03 & \\
\hline
\end{tabular}

Notes: Standard errors are in parentheses. Significance levels are indicated as $1 \%(* * *), 5 \%(* *)$ and $10 \%(*)$. No regression results are reported for reform index values over $[-0.8862,-0.8002)$ because this interval contains too few observations.

${ }^{1}$ Chow test statistic maximum for the presence of another structural break. Bold font indicates that the break is significant. 
Table A4 Structural Breaks in a Model of Growth without School Enrollment and Population Growth

\begin{tabular}{|c|c|c|c|c|c|c|c|c|c|c|c|c|}
\hline $\begin{array}{l}\text { Index range: } \\
\text { Stability of model: }\end{array}$ & \begin{tabular}{|r} 
Full sample \\
Unstable m \\
$(1)$
\end{tabular} & lodel & $\begin{array}{r}\text { [Min; -0.80 } \\
\text { Unstable m } \\
(2) \\
\end{array}$ & & $\begin{array}{c}\text { Min; } \mathbf{- 0 . 8 8} \\
\text { Stable mod } \\
(3) \\
\end{array}$ & & $\begin{array}{c}{[-0.8002, \mathbf{M}} \\
\text { Unstable m } \\
(4)\end{array}$ & & $\begin{array}{c}-0.8002,0 \\
\text { Stable mod } \\
(5)\end{array}$ & 191) & $\begin{array}{r}0.7191 ; \mathrm{M} \\
\text { Stable } \\
(6) \\
\end{array}$ & lel \\
\hline Reform index & $-2.769 *$ & $(1.693)$ & $-25.390 * * *$ & $(8.621)$ & $-28.107 * * *$ & $(10.640)$ & $-3.123^{*}$ & $(1.831)$ & -2.570 & $(2.349)$ & -3.598 & $(2.640)$ \\
\hline Reform index lagged & $6.850^{* * *}$ & $(1.630)$ & $52.275^{* * *}$ & $(9.307)$ & $54.631 * * *$ & (11.402) & $6.048^{* * *}$ & $(1.468)$ & $5.267 * * *$ & $(1.822)$ & $4.162 *$ & $(2.141)$ \\
\hline Democracy & $-10.695 * * *$ & $(2.220)$ & 1.324 & $(5.384)$ & 1.651 & $(5.409)$ & $-9.394 * * *$ & $(2.447)$ & $-16.549 * * *$ & $(3.673)$ & 2.095 & $(2.582)$ \\
\hline Inflation (log) & $-1.615^{* * *}$ & $(0.251)$ & $-1.765^{* * *}$ & $(0.521)$ & $-1.783 * * *$ & $(0.557)$ & $-1.642 * * *$ & $(0.299)$ & $-1.929 * * *$ & $(0.404)$ & 0.410 & $(0.369)$ \\
\hline War Dummy & $-9.436^{* * *}$ & $(1.429)$ & $-10.221 * * *$ & $(2.263)$ & $-11.903 * * *$ & (2.174) & $-7.617 * * *$ & $(1.923)$ & $-8.477 * * *$ & $(2.205)$ & & \\
\hline EBRD IC1 measure & 0.254 & $(0.242)$ & -0.673 & $(0.739)$ & -1.178 & $(0.734)$ & 0.235 & $(0.230)$ & $0.893^{* *}$ & $(0.366)$ & $-0.434 * *$ & $(0.205)$ \\
\hline Intercept & $11.550^{* * *}$ & (1.504) & $35.937 * * *$ & $(8.458)$ & $35.151 * * *$ & (13.109) & $11.484 * * *$ & $(1.519)$ & $16.049 * * *$ & $(2.025)$ & 1.622 & $(2.003)$ \\
\hline $\mathrm{R}^{2}$ & 0.576 & & 0.613 & & 0.648 & & 0.535 & & 0.571 & & 0.120 & \\
\hline F-stat / p-value & 64.89 & 0.00 & 17.16 & 0.00 & 16.90 & 0.00 & 41.21 & 0.00 & 29.67 & 0.00 & 2.05 & 0.08 \\
\hline $\mathrm{N}$ & 294 & & 72 & & 62 & & 222 & & 141 & & 81 & \\
\hline Potential break located at & -0.8002 & & -0.8862 & & -0.968 & & 0.7191 & & 0.3785 & & 1.4430 & \\
\hline Chow test stat ${ }^{1}$ & 7.00 & & 2.54 & & 2.09 & & 3.28 & & 1.87 & & 1.17 & \\
\hline Critical value & 1.94 & & 2.13 & & 2.13 & & 1.98 & & 2.03 & & 2.03 & \\
\hline
\end{tabular}

Notes: Standard errors are in parentheses. Significance levels are indicated as $1 \%(* * *), 5 \%(* *)$ and $10 \%(*)$. No regression results are reported for reform index values over $[-0.8862,-0.8002)$ because this interval contains too few observations.

${ }^{1}$ Chow test statistic maximum for the presence of another structural break. Bold font indicates that the break is significant. 


\section{DAVIDSON INSTITUTE WORKING PAPER SERIES - Most Recent Papers}

The entire Working Paper Series may be downloaded free of charge at: www.wdi.bus.umich.edu

CURRENT AS OF $1 / 23 / 04$

\begin{tabular}{|c|c|c|}
\hline Publication & Authors & Date \\
\hline $\begin{array}{l}\text { No. 643: Mind the Break! Accounting for Changing Patterns of Growth } \\
\text { during Transition }\end{array}$ & Jan Fidrmuc and Ariane Tichit & Jan. 2004 \\
\hline No. 642: The Monetary Approach to Exchange Rates in the CEECs & $\begin{array}{l}\text { Jesús Crespo-Cuaresma, Jarko } \\
\text { Fidrmuc and Ronald MacDonald }\end{array}$ & Jan. 2004 \\
\hline $\begin{array}{l}\text { No. 641: Community Norms and Organizational Practices: The } \\
\text { Legitimization of Wage Arrears in Russia, 1992-1999 }\end{array}$ & $\begin{array}{l}\text { John S. Earle, Andrew Spicer and } \\
\text { Klara Sabirianova Peter }\end{array}$ & Jan. 2004 \\
\hline No. 640: Trust in Transition: Cross Country and Firm Evidence & $\begin{array}{l}\text { Martin Raiser, Alan Rousso, and } \\
\text { Franklin Steves }\end{array}$ & Jan. 2004 \\
\hline $\begin{array}{l}\text { No. 639: What Makes Small Firms Grow? Finance, Human Capital, } \\
\text { Technical Assistance, and the Business Environment in Romania }\end{array}$ & $\begin{array}{l}\text { J. David Brown, John S. Earle } \\
\text { and Dana Lup }\end{array}$ & Jan. 2004 \\
\hline $\begin{array}{l}\text { No. 638: The Politics of Economic Reform in Thailand: Crisis and } \\
\text { Compromise }\end{array}$ & Allen Hicken & Jan. 2004 \\
\hline $\begin{array}{l}\text { No. 637: How Much Restructuring did the Transition Countries } \\
\text { Experience? Evidence from Quality of their Exports }\end{array}$ & Yener Kandogan & Jan. 2004 \\
\hline $\begin{array}{l}\text { No. 636: Estimating the Size and Growth of Unrecorded Economic } \\
\text { Activity in Transition Countries: A Re-Evaluation of Eclectric } \\
\text { Consumption Method Estimates and their Implications }\end{array}$ & Edgar L. Feige and Ivana Urban & Dec. 2003 \\
\hline No. 635: Measuring the Value Added by Money & Vlad Ivanenko & Nov. 2003 \\
\hline $\begin{array}{l}\text { No. 634: Sensitivity of the Exporting Economy on the External Shocks: } \\
\text { Evidence from Slovene Firms }\end{array}$ & $\begin{array}{l}\text { Janez Prašnikar, Velimir Bole, } \\
\text { Aleš Ahcan and Matjaž Koman }\end{array}$ & Nov. 2003 \\
\hline $\begin{array}{l}\text { No. 633: Reputation Flows: Contractual Disputes and the Channels for } \\
\text { Inter-firm Communication }\end{array}$ & William Pyle & Nov. 2003 \\
\hline $\begin{array}{l}\text { No. 632: The Politics of Development Policy and Development Policy } \\
\text { Reform in New Order Indonesia }\end{array}$ & Michael T. Rock & Nov. 2003 \\
\hline $\begin{array}{l}\text { No. 631: The Reorientation of Transition Countries' Exports: } \\
\text { Changes in Quantity, Quality and Variety }\end{array}$ & Yener Kandogan & Nov. 2003 \\
\hline $\begin{array}{l}\text { No. 630: Inequality of Outcomes and Inequality of Opportunities in } \\
\text { Brazil }\end{array}$ & $\begin{array}{l}\text { François Bourguignon, Francisco } \\
\text { H.G. Ferreira and Marta } \\
\text { Menéndez }\end{array}$ & Nov. 2003 \\
\hline No. 629: Job Search Behavior of Unemployed in Russia & Natalia Smirnova & Nov. 2003 \\
\hline $\begin{array}{l}\text { No. 628: How has Economic Restructuring Affected China's Urban } \\
\text { Workers? }\end{array}$ & John Giles, Albert Park, Feng Cai & Oct. 2003 \\
\hline No. 627: The Life Cycle of Government Ownership & Jiahua Che & Oct. 2003 \\
\hline $\begin{array}{l}\text { No. 626: Blocked Transition And Post-Socialist Transformation: Siberia } \\
\text { in the Nineties }\end{array}$ & Silvano Bolcic & Oct. 2003 \\
\hline $\begin{array}{l}\text { No. 625: Generalizing the Causal Effect of Fertility on Female Labor } \\
\text { Supply }\end{array}$ & $\begin{array}{l}\text { Guillermo Cruces and Sebastian } \\
\text { Galiani }\end{array}$ & Oct. 2003 \\
\hline $\begin{array}{l}\text { No. 624: The Allocation and Monitoring Role of Capital Markets: } \\
\text { Theory and International Evidence }\end{array}$ & Solomon Tadesse & Oct. 2003 \\
\hline No. 623: Firm-Specific Variation and Openness in Emerging Markets & $\begin{array}{l}\text { Kan Li, Randall Morck, Fan Yang } \\
\text { and Bernard Yeung }\end{array}$ & Oct. 2003 \\
\hline $\begin{array}{l}\text { No. 622: Exchange Rate Regimes and Volatility: Comparison of the } \\
\text { Snake and Visegrad }\end{array}$ & $\begin{array}{l}\text { Juraj Valachy and Evžen } \\
\text { Kočenda }\end{array}$ & Oct. 2003 \\
\hline $\begin{array}{l}\text { No. 621: Do Market Pressures Induce Economic Efficiency?: The Case } \\
\text { of Slovenian Manufacturing, 1994-2001 }\end{array}$ & $\begin{array}{l}\text { Peter F. Orazem and Milan } \\
\text { Vodopivec }\end{array}$ & Oct. 2003 \\
\hline $\begin{array}{l}\text { No. 620: Compensating Differentials in Emerging Labor and Housing } \\
\text { Markets: Estimates of Quality of Life in Russian Cities }\end{array}$ & $\begin{array}{l}\text { Mark C. Berger, Glenn C. } \\
\text { Blomquist and Klara Sabirianova } \\
\text { Peter }\end{array}$ & Oct. 2003 \\
\hline $\begin{array}{l}\text { No. 619: Are Foreign Banks Bad for Development Even If They Are } \\
\text { Efficient? Evidence from the Indian Banking Sector }\end{array}$ & $\begin{array}{l}\text { Sumon Bhaumik and Jenifer } \\
\text { Piesse }\end{array}$ & Oct. 2003 \\
\hline No. 618: The Echo of Job Displacement & $\begin{array}{l}\text { Marcus Eliason and Donald } \\
\text { Storrie }\end{array}$ & Oct. 2003 \\
\hline
\end{tabular}

